\title{
The effect of oral care given to patients on mechanical ventilatory support by two different methods on bacterial colonization in oral mucosa and oral health
}

\section{Mekanik ventilatör desteğindeki hastalara iki farklı yöntemle verilen ağız bakımının oral mukozadaki bakteriyel kolonizasyon ve ağız sağlığı üzerine etkisi}

\author{
(1) Ayşe Tali, ${ }^{1}$ (1) Elif Karahan, 2 (1) Füsun Cömert ${ }^{3}$ \\ 'Institute of Health Sciences, Bülent Ecevit University, Zonguldak, Turkey \\ ${ }^{2}$ Department of Nursing, Faculty of Health Sciences, Bülent Ecevit University, Zonguldak, Turkey \\ ${ }^{3}$ Department of Medical Microbiology, Belent Ecevit University Faculty of Medicine, Zonguldak, Turkey
}

\begin{abstract}
Introduction: The aim of the study was to examine oral care given to the patients on mechanical ventilatory support by two different methods on bacterial colonization and oral health.

Methods: This study had a design including an experimental and a control group. Sample was composed of 30 patients who had mechanical ventilatory support less than 24 hours. Patients in the experimental group were applied toothbrush and serum physiological; and control group was applied oral care by abeslang and a sponge soaked with $\mathrm{NaHCO}_{3}$. Both groups were given oral care four times a day for four days. Oral health was evaluated by "oral assessment scale", and bacterial colonization was assessed based on bacteriological culture results of samples taken by cotton swab at days 1 and 4 .

Results: It was found that almost half of the patients in both groups had insufficient saliva that was more viscous than normal; and dental plaques were decreased among the patients in the experimental group. In terms of bacteria in the oral mucosa, no statistically significant differences were found between the groups based on the comparison of culture results from days 1 and 4 . It was found that both methods used for oral care were effective; and they had no superiority over each other.

Discussion and Conclusion: It was concluded that application of regular oral care for the patients on mechanical ventilatory support as part of care protocols decreased bacterial colonization and had a protective and improving effect on oral health.
\end{abstract}

Keywords: Mechanical ventilator; oral care; oral mucosa; toothbrush; intensive care.
Özet

Amaç: Mekanik ventilatör desteğindeki hastalarda iki farklı yöntemle verilen ağız bakımının oral mukozadaki bakteriyel kolonizasyon ve ağız sağlığı üzerine olan etkisinin incelenmesidir.

Gereç ve Yöntem: Araştırma, deneysel kontrollü çalışma tasarımı ile yürütülmüştür. Örneklemi, en az 24 saat mekanik ventilatör desteği alan 30 hasta oluşturmuştur. Deney grubundaki hastalara serum fizyolojik ve diş firçası ile kontrol grubundaki hastalara $\mathrm{NaHCO}_{3}$ ile ıslatılmış spanç ve abeslang ile ağız bakımı uygulanmıştır. Her iki gruba da dört gün süreyle günde dört kez ağız bakımı verilmiştir. Ağız sağlığı "ağız değerlendirme ölçeği" ile, bakteri kolonizasyonu ise 1. ve 4. gün pamuklu eküvyon çubukla ağızdan alınan örneklerin bakteriyolojik kültür sonuçlarına göre değerlendirilmiştir.

Bulgular: Hastalara verilen dört günlük ağız bakımı sonucunda her iki grupta da hastaların yarısına yakınında tükürüğünün yetersiz ve normalden daha yoğun olduğu; deney grubundaki hastaların diş plaklarında azalma olduğu görülmüştür. Ağız mukozasında bulunan bakteriler bakımından, 1. ve 4. gün alınan kültür sonuçlarının karşılaştırılmasına göre gruplar arasında istatistiksel olarak anlamlı farklıı̆̆ın olmadığı belirlenmiştir. Ağız bakımında kullanılan her iki yöntemin de etkin ancak birbirine üstünlüklerinin olmadığı saptanmıştır.

Sonuç: Mekanik ventilatör desteğindeki hastalar için bakım protokolleri çerçevesinde düzenli ağız bakımı yapılmasının bakteri kolonizasyonunu azalttığı, ağız sağlığını koruyucu ve geliş̧irici etkisi görülmüştür.

Anahtar Sözcükler: Mekanik ventilatör; ağız bakımı; ağız mukozası, diş fırçası; yoğun bakım.

Corresponding (illetişim): Elif Karahan, Bülent Ecevit Üniversitesi Sağlık Bilimleri Fakültesi, Hemşirelik Bölümü, Esenköy, Zonguldak, Turkey E-mail (E-posta): elifim67@yahoo.com 
$\mathrm{M}^{\mathrm{c}}$ echanical ventilation is used to support or provide respiration of the patients having respiratory failure by increasing alveolar ventilation. Mechanical ventilators are used for carrying out respiratory functions. Pathogen colonization is commonly seen especially among the patients who undergo ventilation treatment. Some of the causes are the lack of using appropriate techniques in airway aspiration, lack of swallowing reflexes and oropharyngeal contamination. ${ }^{[1]}$

It is highly important to maintain oral mucosa integrity in patients on mechanical ventilatory support. Among the patients with mechanical ventilatory support, medication used for treatment, inability of the patients to take liquids or foods by mouth, systemic dehydratation, dryness in oral mucosa due to stress and tachypnea, increase in sympathic stimulation and decrease in saliva secretion due to lack of nutrition may affect oral mucosa health negatively. Besides, presence of endotracheal tube, presence of pressure on the mucosa, permanent opening of the mouth and adhesive bands or bandages used for the detection of endotracheal tube may cause a disturbance in the integrity of mouth and surrounding tissues. ${ }^{[2-4]}$

When sufficient oral hygiene could not be provided in the intensive care patients who could not meet individuals needs independently and who were followed up mostly under sedation, oral problems such as bad breath, alterations in the sense of taste, gingivitis, mouth dryness, lip cracks, stomatitis and mouth ulcers have been observed. ${ }^{[5]}$ Moreover, entry of the bacteria into respiratory tract is facilitated in these patients due to endotracheal tube; and secretion is increased by accompanying disturbance in coughing reflex. The increase in secretion causes changes in the oral flora and formation of dental plaques due to the replacement of gram positive bacteria, which generate normal flora in the mouth, by gram negative bacteria. ${ }^{[4,6]}$ These changes also increase the risk for developing ventilator-associated pneumonia (VAP) among the patients on mechanical ventilatory support. ${ }^{[7]}$ Considering the effect of VAP on the duration of hospitalization and its cost analysis, it was indicated that care costs of a patient increased by 30.000-40.000 dollars with the extension of the duration of hospitalization due to VAP for an average of ten days. The development of these problems is also important in terms of increasing mortality rates as well as extending the hospitalization time in the intensive care unit. A regular oral care should be implemented as part of care protocols in order to prevent these problems and to enhance quality of care. ${ }^{[4,8]}$

In the literature, there is not an absolute evidence regarding the frequency of oral care; but there are different data. Data retrieved by daily assessment of oral mucosa may be guiding for determining the frequency of oral care. ${ }^{[3,9]}$ In the literature, the use of toothbrush for oral care has been reported to be the best and most effective tool for the patients on mechanical ventilatory support. ${ }^{[10,11]}$ Based on the results of evidence-based studies, it was observed that use of soft toothbrushes decreased microbial colonization by removing plaques and foreign substances found in the mouth. ${ }^{[12]}$ It was reported that oral care applied by toothbrush was more effective than oral care by sponge sticks among the patients on mechanical ventilatory support; oral care by sponge sticks was insufficient for cleaning dental plaques and therefore, toothbrush was required to be used as long as there was no risk of pain and bleeding. ${ }^{[2,10]}$

In recent years, vacuum toothbrushes have been used for oral care of the patients on mechanical ventilatory support in order to prevent the formation of plaques and infection. Vacuum toothbrushes, that are simple and effective products for providing oral hygiene, protect health of oral mucosa by brushing the teeth and maintain the openness of airway by preventing the formation of mucus, plaque and bacteria inside the mouth due to its feature of aspiration. ${ }^{[12,13]}$

The number of studies for the use of toothbrushes in patients, whose respirations are supported by mechanical ventilation, is limited. This study was carried out to determine the effects of oral care given by two different methods to the patients getting mechanical ventilatory support on bacterial colonization in oral mucosa and oral health.

\section{Materials and Method}

\section{Design}

The study was carried out experimentally to determine the effects of oral care given by two different methods to the patients on mechanical ventilatory support.

\section{Setting}

The study was conducted between 03.26.2017 and 02.20.2018. It was carried out in Anaesthesia and Reanimation Intensive Care and General Intensive Care Units of Bulent Ecevit University Health Practice and Research Center. In these intensive care units, each nurse was providing care for an average of three patients. The maintenance of oral care was the responsibility of the nurse. Oral care was routinely provided for the patients on mechanical ventilatory support in these intensive care units by sponges soaked with $\mathrm{NaHCO}_{3}$ and abeslang for four times a day or as frequent as the patients needed.

\section{Sample}

The universe of the study included patients who underwent mechanical ventilation treatment in Anaesthesia and Reanimation Intensive Care and General Intensive Care Units of Bulent Ecevit University Health Practice and Research Center. During one year period, a total of 216 patients underwent mechanical ventilation treatment. Sample of the study was composed of patients who had mechanical ventilatory support by endotracheal intubation method for less than 24 hours and who did not have any oral care during this period, whose mechanical ventilatory support continued at least for four days, who did not have any respiration-associated infectious pathogens and who did not have oral problems such as stomatitis, mouth ulcer, candidiasis and gingivitis. 126 patients were not eligible for study inclusion criteria and excluded from the study. 25 patients were also excluded due to early 
extubation and 35 patients were excluded due to the development of eksitus. The sample was composed of 30 patients. Sample power was calculated as $70 \%$ including an effect size of 0.81 . The first patient who assigned to the sample group was determined by lot using simple random method. Then, patients were classified as experimental $(n=15)$ and control $(n=15)$ groups.

\section{Instruments and Data Collection}

A patient identification and follow-up form, oral assessment scale and culture results of oral samples were used for data collection. Factors, that were thought to affect oral health, were evaluated by patient identification and follow-up form. ${ }^{[2,3]}$ Oral assessment scale that was used to evaluate oral cavity in the study was developed by Eilers et al. ${ }^{[14]}$ and revised by Yates. ${ }^{[15]}$ The reliability of oral assessment scale was 0.91 . This scale was composed of five parts including lips, oral mucosa gum, tongue, teeth and saliva. Each part was scored between 1-4; and total score of oral assessment scale ranged between 4-20. In terms of oral mucosa health, an oral assessment scale score less than 5 was considered as normal, between 6-10 as mild dysfunction, between 11-15 as moderate dysfunction and between 16-20 as severe dysfunction. ${ }^{[15]}$

Two distinct oral care protocols were used in the study. Patients were randomly assigned to experimental and control groups. Patients in the experimental group were given serum physiological, low pressure aspirator and toothbrush; and patients in the control group were applied oral care by sponge soaked with $\mathrm{NaHCO}_{3}$ and abeslang. Oral care protocols were applied by the same researcher for each patient four times a day during four days. Assessments were made based on patient follow-up and oral assessment scale at days 1 and 4; and oral sampling was made for culture by the same researcher. Cultures of oral samples were evaluated by the same specialist in the same laboratory.

Oral samples were taken at days 1 and 4 before the implementation of oral care. Samples that were taken by a cotton swab were inoculated on a bloody, chocolate-like and EMB (EosinMethylene Blue) agars (Oxoid). Bloody and chocolate-like agars were incubated under the condition of $5 \% \mathrm{CO}_{2}$, and $\mathrm{EMB}$ agars were incubated at normal athmospheric conditions at $37^{\circ} \mathrm{C}$ for 48 hours. Agar plaques were evaluated for growth at 24 and 48 hours following incubation. Grown bacteria were identified by traditional methods; ${ }^{[16]}$ and APISTREP, API E, API NE and API Coryne kits were used as bacterial identification kits when required.

\section{Ethical Considerations}

An ethics committee approval was obtained from non-interventional Clinical Research Ethics Committee of Kocaeli University. An institutional authorization was taken from Zonguldak Bulent Ecevit University Health Practice and Research Center in order to conduct the study. The guardians of the patients included in the sample group provided informed consents.

\section{Data Analysis}

Data obtained in the study were assessed by using SPSS (Statistical Package for Social Science) 19.0 package program. Numbers, percentages and mean analyses were used to evaluate variables that were included in patient identification and follow-up form and oral assessment scale. Pearson Chi-Square test, Fisher Exact test, $t$ test and Mann Whitney $U$ were used to compare groups. McNemar test was used to compare categorical data within the groups.

\section{Limitations}

Due to the difficulties in providing vacuum toothbrushes, oral care was applied by low pressure aspirators in experimental group. 186 patients, who did not meet inclusion criteria, were excluded from the study. Seven patients, who did not have teeth, were enrolled in the control groups due to the difficulties in finding sufficient number of patients meeting inclusion criteria.

\section{Results}

Both groups were found to be similar based on patients' age, sex, reason for hospitalization in intensive care, their states of having regular oral care before hospitalization, bacteria grown as a result of tracheal aspirate, APACHE (Acute Physiology and Chronic Health Evaluation), SAPS II (Simplified Acute Physiology Score) and Glasgow Coma Scale $(p>0,05)$. Patients, who were lacking teeth, were significantly more in control group $(p=0,006)$ (Table 1).

At assessments of the patients in experimental and control groups at days 1 and 4, medications causing alterations in oral mucosa, state of enteral nutrition, body temperature, leukocyte count, thrombocyte count, characteristics of oral secretions, $\mathrm{PaO}_{2}$ and $\mathrm{FiO}_{2}$ values and lung sounds were found to be comparable ( $p>0,05)$ (Table 2).

Based on oral assessment scale, it was observed that lips, oral mucosa and gums were smooth, pink-colored, wet and intact in most of the patients in experimental and control groups at days 1 and 4; and among most of the patients, tongues were less dry, red areas and papillae were evident on a number of fields and a mild whitening was observed. For the assessment of teeth in the same scale, very few debris was found in almost half of the patients in both groups and debris was mostly like a visible plaque between teeth. In the assessment of saliva, it was seen that saliva was inadequate, more viscous than normal and was causing a difficulty in swallowing in nearly half of the patients. Groups were found to be similar based on oral assessment scale ( $p>0,05)$ (Table 3 ).

In this study, bacteria that were identified in oral culture were Streptococcusoralis, Corynebacteriumstriatum, Methyciline resistant coagulase negative staphylococcus (MRKNS), germ tube negative yeast, Candidaalbians, Enterobactercloacae, Enterococcusspp, Klebsiellapneumoniae, Escherichia. coli, 


\section{Table 1. Patient demographics}

\begin{tabular}{|c|c|c|c|c|c|c|}
\hline \multirow[t]{2}{*}{ Characteristics } & \multicolumn{2}{|c|}{$\begin{array}{l}\text { Experimental } \\
\qquad(n=15)\end{array}$} & \multicolumn{2}{|c|}{$\begin{array}{l}\text { Control } \\
(n=15)\end{array}$} & \multirow[t]{2}{*}{$X^{2}-t$} & \multirow[t]{2}{*}{ p value } \\
\hline & $\mathbf{n}$ & $\%$ & $\mathbf{n}$ & $\%$ & & \\
\hline $18-40$ & 2 & 13.30 & 1 & 6.60 & & \\
\hline $41-65$ & 6 & 40.00 & 4 & 26.70 & & \\
\hline Male & 7 & 46.70 & 10 & 66.70 & & \\
\hline Female & 8 & 53.30 & 5 & 33.30 & & \\
\hline Reason for hospitalization & & & & & $X^{2}=3.105$ & 0.540 \\
\hline Loss of consciousness & 2 & 13.30 & 3 & 20.00 & & \\
\hline Arrest after & 2 & 13.30 & 5 & 33.30 & & \\
\hline Regular oral care before hospitalization & & & & & $X^{2}=1.677$ & 0.195 \\
\hline Yes & 10 & 66.70 & 13 & 86.70 & & \\
\hline No & 5 & 33.30 & 2 & 13.30 & & \\
\hline Number of teeth & & & & & $X^{2}=10.196$ & 0.006 \\
\hline Normal & 5 & 33.30 & 1 & 6.60 & & \\
\hline Missing teeth & 10 & 66.70 & 7 & 46.70 & & \\
\hline None dental & 0 & 0.00 & 7 & 46.70 & & \\
\hline A result of tracheal aspirate & & & & & $X^{2}=10.152$ & 0.255 \\
\hline Reproduction None & 7 & 46.70 & 4 & 26.70 & & \\
\hline Normal respiratory flora & 1 & 6.70 & 3 & 20.00 & & \\
\hline Aspergillus & 1 & 6.70 & 0 & 0.00 & & \\
\hline Scales & & & & & $X^{2}=2.182$ & 0.336 \\
\hline \multicolumn{7}{|l|}{ GKS Skore } \\
\hline 3 & 10 & 66.70 & 12 & 80.00 & & \\
\hline $4-6$ & 2 & 13.30 & 0 & 0.00 & & \\
\hline \multirow[t]{2}{*}{$7-11$} & 3 & 20.00 & 3 & 20.00 & & \\
\hline & Mean & SD & Mean & SD & & \\
\hline APACHE & 26.6 & 5.705 & 30.8 & 6.581 & $\mathrm{t}=-1.868$ & 0.072 \\
\hline SAPS II & 56.73 & 13.72 & 61.06 & 14.33 & $\mathrm{t}=-0.846$ & 0.405 \\
\hline
\end{tabular}

COPD: Chronic obstructive pulmonary disease; GKS: Glasgow Coma Scale; APACHE: Acute Physiology and Chronic Health Evaluation; SAPS II: Simplified Acute Physiology Score; SD: Standard deviation.

Methyciline sensitive coagulase negative staphylococcus, Methyciline sensitive Staphylococcus aureus, Acinetobacter baumanii, Pseudomonas aeruginosa and Micrococcus spp. Comparison of the bacteria found in oral mucosa at days 1 and 4 based on groups was given in Table 2. No significant differences were found between culture growth of the bac- teria found in the samples at days 1 and 4 based on experimental and control groups $(p>0,05)$. At the end of oral care applied four times a day for four days, bacterial colonizations were found to be decreased or similar except Klebsiellapneumonie, E. Coli and Micrococcusspp in both groups at days 1 and 4 (Table 4). 


\section{Table 2. Comparison of $1^{\text {st }}$ and $4^{\text {th }}$ day group distributions according to the treatment/care approach of patients}

\section{Characteristics}

\begin{tabular}{lr}
\multicolumn{2}{c}{$\begin{array}{c}\text { Experimental } \\
(n=15)\end{array}$} \\
\hline$n$ & $\%$
\end{tabular}

Number of drugs used* (day $1^{\text {st }}$ )

$$
1-3
$$

4 and more

Number of drugs used* (day $4^{\text {th }}$ )

$$
1-3
$$

4 and more

State of enteral nutrition (day $1^{\text {st) }}$

Feeding

Not feed

State of enteral nutrition (day $4^{\text {th }}$ )

Feeding

Not feed

Body temperature (day $1^{\text {st }}$ )

$$
\text { 36-37 }
$$

37.1-37.9

38 and more

Body temperature (day $4^{\text {th }}$ )

$$
\text { 36-37 }
$$

37.1-37.9

38 and more

Leukocyte count (day $1^{\text {st }}$ )

Normal

Leukocytosis

Leukopenia

Leukocyte count (day $4^{\text {th }}$ )

Normal

Leukocytosis

Leukopenia

Thrombocyte count (day $1^{\text {st }}$ )

Normal

Thrombocytosis

Thrombocytopenia

Thrombocyte count (day $4^{\text {th }}$ )

Normal

Thrombocytosis

Thrombocytopenia

Oral secretions (day $1^{\text {st }}$ )

Serous

Mucolytic

Purulent

Hemorrhagic

Oral secretions (day $4^{\text {th }}$ )

Serous

Mucolytic

Purulent

Hemorrhagic

$\mathrm{PaO}_{2}$ values (day $1^{\text {st}}$ )

79 and below

80-100

101 and above

8

7

8

8
7

1

14

6

9

12

3

0

11

2

2

0

11

4

2

9

4

8

1

6

8

1

6

2

1

10

2

3

1

9

2

7

1

7
Control

(n=15)

n $\%$

53.30

46.70

10

5

53.30

46.70

6.70

93.30

40.00

60.00

80.00

20.00

0.00

73.40

13.30

13.30

0.00

73.30

26.70

13.30

60.00

26.70

53.30

6.70

40.00

53.30

6.70

40.00

13.30

6.70

66.70

13.30

20.00

6.70

60.00

13.30

46.70

6.60

46.70
66.70

33.30

60.00

40.00

20.00

80.00

53.30

46.70

73.30

20.00

6.70

66.70

20.00

13.30

26.70

60.00

13.30

33.30

46.70

20.00

73.30

0.00

26.70

60.00

13.30

26.70

46.70

0.00

46.70

6.60

33.30

6.70

60.00

0.00

6.70

33.30

60.00
$X^{2}=0.556 / p=0.355$

$X^{2}=0.381 / p=0.827$

$X^{2}=2.500 / p=0.475$

$X^{2}=4.867 / p=0.088$

$X^{2}=1.679 / p=0.432$

$X^{2}=1.874 / p=0.392$

$\mathrm{X}^{2}=2.877 / \mathrm{p}=0.237$

$X^{2}=4.641 / p=0.200$

$\mathbf{X}^{2} / \mathbf{P}$

$X^{2}=0.136 / p=0.500$

$X^{2}=1.154 / p=0.299$

$X^{2}=0.536 / p=0.358$

$X^{2}=1.043 / p=0.593$

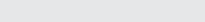

$x^{2}=4.641 / p=0.200$

$X^{2}=7.417 / p=0.025$ 
Table 2 (Cont.). Comparison of $1^{\text {st }}$ and $4^{\text {th }}$ day group distributions according to the treatment/care approach of patients

\begin{tabular}{|c|c|c|c|c|c|}
\hline \multirow[t]{2}{*}{ Characteristics } & \multicolumn{2}{|c|}{$\begin{array}{l}\text { Experimental } \\
\quad(n=15)\end{array}$} & \multicolumn{2}{|c|}{$\begin{array}{l}\text { Control } \\
(n=15)\end{array}$} & \multirow[t]{2}{*}{$X^{2} / P$} \\
\hline & $\mathbf{n}$ & $\%$ & $\mathbf{n}$ & $\%$ & \\
\hline $\mathrm{PaO}_{2}$ values (day $4^{\text {th }}$ ) & & & & & $\mathrm{X}^{2}=2.800 / \mathrm{p}=0.247$ \\
\hline 79 and below & 3 & 20.00 & 2 & 13.30 & \\
\hline $80-100$ & 4 & 26.70 & 1 & 6.70 & \\
\hline 101 and above & 8 & 53.30 & 12 & 80.00 & \\
\hline $\mathrm{FiO}_{2}$ values (day $1^{\text {st }}$ ) & & & & & $X^{2}=3.404 / p=0.182$ \\
\hline $0-40$ & 2 & 13.30 & 1 & 6.70 & \\
\hline $41-60$ & 6 & 40.00 & 11 & 73.30 & \\
\hline 61 and above & 7 & 46.70 & 3 & 20.00 & \\
\hline $\mathrm{FiO}_{2}$ values (day $4^{\text {th }}$ ) & & & & & $X^{2}=0.168 / p=0.920$ \\
\hline $0-40$ & 7 & 46.70 & 6 & 40.00 & \\
\hline $41-60$ & 5 & 33.30 & 6 & 40.00 & \\
\hline 61 and above & 3 & 20.00 & 3 & 20.00 & \\
\hline Lung sounds (day $1^{\text {st }}$ ) & & & & & $X^{2}=3.921 / p=0.687$ \\
\hline Normal & 3 & 20.00 & 4 & 26.70 & \\
\hline Rough breathing & 2 & 13.30 & 1 & 6.70 & \\
\hline Raller & 4 & 26.70 & 5 & 33.20 & \\
\hline Ronkus & 1 & 6.70 & 1 & 6.70 & \\
\hline Raller and roncus & 2 & 13.30 & 0 & 0.00 & \\
\hline Breathing sound reduction & 1 & 6.70 & 3 & 20.00 & \\
\hline Unheard of sound & 2 & 13.30 & 1 & 6.70 & \\
\hline Lung sounds (day $4^{\text {th }}$ ) & & & & & $X^{2}=3.067 / p=0.800$ \\
\hline Normal & 2 & 13.30 & 2 & 13.30 & \\
\hline Rough breathing & 3 & 20.00 & 3 & 20.00 & \\
\hline Raller & 4 & 26.70 & 6 & 40.00 & \\
\hline Ronkus & 1 & 6.70 & 1 & 6.70 & \\
\hline Raller and roncus & 2 & 13.30 & 0 & 0.00 & \\
\hline Breathing sound reduction & 1 & 6.70 & 2 & 13.30 & \\
\hline Unheard of Sound & 2 & 13.30 & 1 & 6.70 & \\
\hline
\end{tabular}

*Antibiotics, corticosteroids, antihistamines, anticholinergics, tranklizans, anticonvulsants, antihypertensives, $\mathrm{H} 2$ receptor antogonists, bronchodilators, betablocytes, drugs containing tricyclic antidepressants, antipsychotics, benzodiazepines, atropinics.

\section{Discussion}

In recent years, the importance of oral care has been highly emphasized in order to prevent VAP due to the similarities of bacteria found inside the mouth and bacteria that were identified in the lungs among the patients on mechanical ventilatory support. Oral care can be implemented by various tools and solutions at different frequencies. In the study by Berry et al., it was indicated that the frequency of oral care varied based on the conditions of the patients, and it should be given by toothbrush at least two times per day ${ }^{[8]}$ Cutler et al. stated that oral care, that was given every 2-4 hours, accelerated healing. ${ }^{[9]}$ Again in this study, oral care was applied four times a day. The increase in dental plaques caused the accumulation of bacteria in oral mucosa. Dental plaques can be removed by brushing method and these bacteria can also be eliminated. ${ }^{[17]}$ Marino et al. have concluded that toothbrushes were more effective than sponge sticks in cleaning dental plaques. ${ }^{[18]}$ It was also reported that VAP was decreased among the patients, who were given oral care by vacuum toothbrushes and $0.12 \%$ chlorhexidine gluconate solution twice a day, compared to the ones who were applied oral care by sponge sticks and hydrogen peroxide solution six times a day ${ }^{[19]}$ Mori et al. have found that incidence of VAP and bacterial colonization were decreased in patients who were given oral care by toothbrushes three times a day in adult intensive care units compared to the patients who were not. ${ }^{[20]}$ According to the results of a meta-analysis ( $n=1408$ ), it was indicated that toothbrushing method did not decrease the ratio of VAP significantly in general and it did not have a positive effect on mortality and hospitalization in intensive care; and it was also indicated that more research was needed on this subject. ${ }^{[21]}$

In many studies examining the efficiency of various oral care 
Table 3. Comparison of 1 st and $4^{\text {th }}$ day group distribution according to Oral Assessment Scale

\section{Evaluation criteria}

Lips (day $1^{\text {st }}$ )

Smooth, pink, wet, intact

Less creased and dry, one or more reds

Dry and slightly swollen bubbles in one of two places

Very dry and edematous, whole lip with inflammation, diffuse bubble or ulceration

Lips (day $4^{\text {th }}$ )

Smooth, pink, wet, intact

Less creased and dry, one or more reds

Dry and slightly swollen bubbles in one of two places

Very dry and edematous, whole lip with inflammation, diffuse bubble or ulceration

Oral mucosa and gum (day $1^{\text {st }}$ )

Smooth, pink, wet, intact

Wound or red areas in two places

where pale and slightly dry

Dry and slightly swollen, diffuse redness, more than two bubbles, red area

Very dry and edematous, all of the mucosa quite red and inflamed many ulcers

Oral mucosa and gum (day $4^{\text {th }}$ )

Smooth, pink, wet, intact

Wound or red areas in two places

where pale and slightly dry

Dry and slightly swollen, diffuse redness, more than two bubbles, red area

Very dry and edematous, all of the mucosa quite red and inflamed many ulcers

Tongue (day $1^{\text {st}}$ )

Smooth, pink, wet, intact

Less dry, red areas and papillae, mild whitening

Dry and slightly swollen, usually broken but ends and papilla ethanred, a two-place bubble

Quite dry and edematous thick and clogged, fully inflamed, end zone quite red numerous fluffy and ulcer

Tongue (day $4^{\text {th }}$ )

Smooth, pink, wet, intact

Less dry, red areas and papillae, mild whitening

Dry and slightly swollen, usually broken but ends and papilla ethanred, a two-place bubble

Quite dry and edematous thick and clogged, fully inflamed, end zone quite red numerous fluffy and ulcer

Tooth (day $1^{\text {st }}$ )

Clean, no debris and plaque

There is very little debris, mostly like a visible plaque between teeth

Moderate amount of debris appears on the tooth enamel or clutched debris

Teeth with debris coated, abraded gingiva

\section{Experimental \\ n}

Control

$X^{2}-U / p$

$\%$

$X^{2}=0.186 / p=0.500$

80.00

20.00

0.00

0.00

$X^{2}=0.848 / p=0.654$

80.0

13.30

6.70

0.00

$X^{2}=2.967 / p=0.227$

13

86.60

11

73.30

26.70

0.00

0.00
80.00

20.00

0.00

0.00

6.70

93.30

0.00

0.00

33.30

66.70

0.00

0.00

0.00

0

$U=57 / p=0.826$

$X^{2}=2.040 / p=0.361$

$X^{2}=1.487 / p=0.475$

$X^{2}=0.000 / p=0.999$

40.00

2

25.00

75.00

2

46.7

6

0 
Table 3 (Cont.). Comparison of 1 st and $4^{\text {th }}$ day group distribution according to Oral Assessment Scale

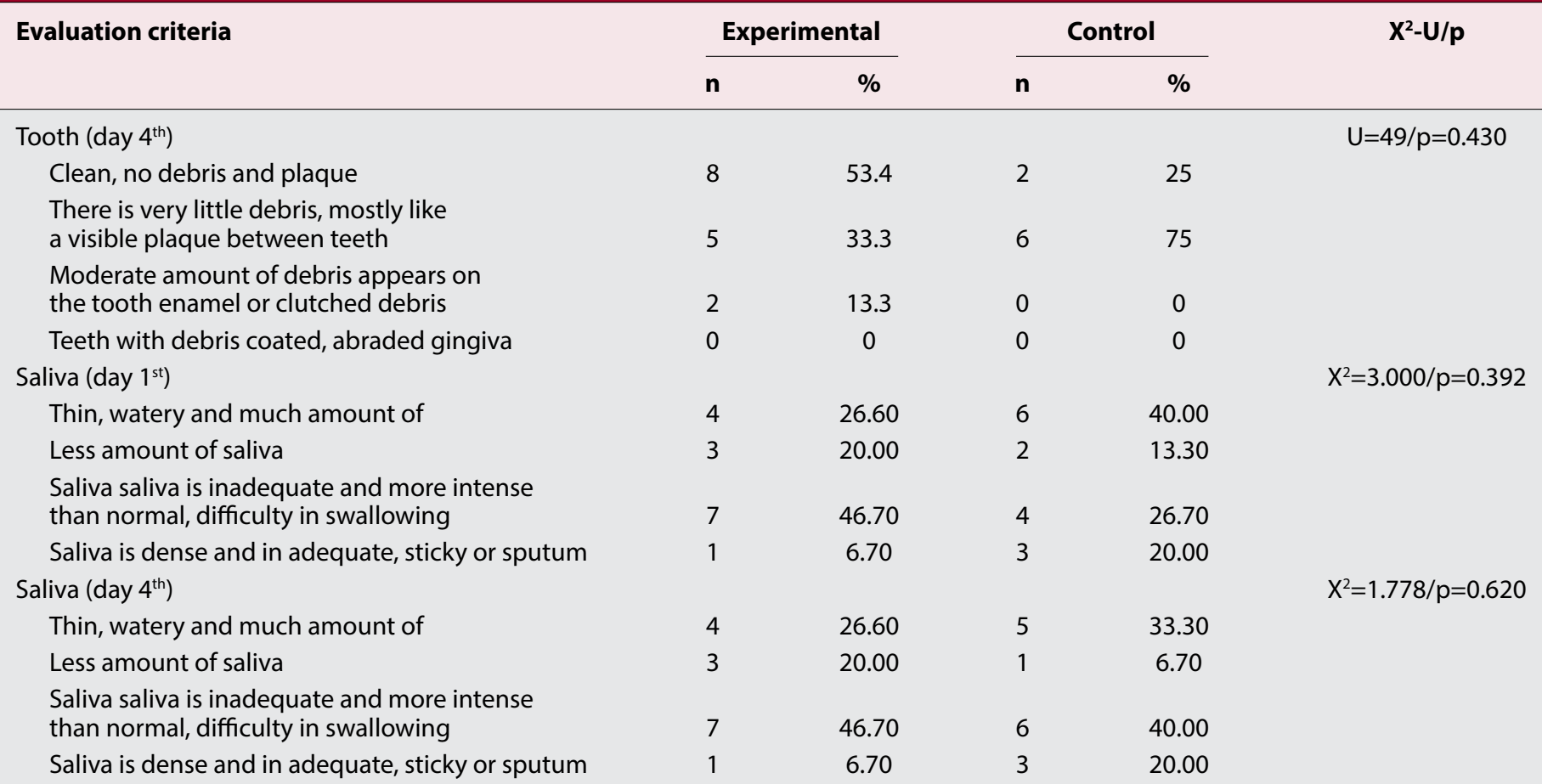

protocols among the patients on mechanical ventilatory support through an experimental design, no significant differences were found in oral bacterial colonization. It was indicated that S. aureus, gram negative bacteria, Klebsiella, Enterobacter, Serretia, Pseudomanas and Acinetobacter species were mostly colonized in oral mucosa. ${ }^{[22-24]}$ In parallel to the relevant literature, similar bacterial species were found to grow in oral mucosa also in this study. In addition to this, bacteria in oral mucosa were found to be decreased or similar between days 1 and 4 following the initiation of oral care protocols. Yao et al. have observed a significant decrease in the cumulative ratio of VAP based on the results of oral care which was provided twice a day for seven days. ${ }^{[24]}$ In this current study, no VAP diagnoses were made in both groups; but, some symptoms and findings that might be associated with VAP were obtained during the assessments made. In both groups, there were patients having a purulent secretion, patients having lung sounds as rales and rhonchi and patients having decreased lung sounds; however, no significant differences were detected between these assessments. Besides, bacteria found in the oral mucosa and bacteria grown in tracheal aspirates were found to be similar; and this reminded that VAP development risk was high among these patients.

Serum physiological and $\mathrm{NaHCO}_{3}$ have been commonly used for oral care in the clinics; and the effect of chlorhexidine was also evaluated in clinical studies. In the study by Berry et al., it was reported that the incidence of VAP was lower among the patients, who were provided oral care by serum physiological and $\mathrm{NaHCO}_{3}$, compared to the ones who were given chlorhexidine; but $\mathrm{NaHCO}_{3}$ was found to have more positive effect on oral mucosa. ${ }^{[12]}$ In the other studies, it was found that chlorhexidine did not have a significant effect on the incidence of VAP compared to toothbrush method. ${ }^{[21,22]}$ In this study, different solutions used for oral care or different cleaning methods such as brushing and abeslang did not change the outcome of bacterial intensity inside the mouth.

In this study, lips, oral mucosa, gum, tongue, teeth and saliva were evaluated for the assessment of oral health. Oral care protocols were applied successfully within 24 hours following the initiation of mechanical ventilatory support treatment; and it was observed during 4-day follow-up period that there was not an impairment in oral health, but there was a mild whitening in most of the patients and saliva was found to be more viscous in nearly half of them. The appearance of debris and plaques was decreased among the patients who underwent oral care by toothbrushes. This situation showed that tooth brushing method was more effective than abeslang in cleaning plaques. In the study by Ozveren, it was indicated that vacuum toothbrush was more effective in oral care and it had an improving effect on oral health. ${ }^{[4]}$ In the study by Marino et al., it was reported that there were significant reductions in gingival index and dental plaques among the patients who were given oral care by toothbrushes. ${ }^{[18]}$ Electrical toothbrushes were found to be more effective than manual toothbrushes in removing plaques and preventing gingivitis. ${ }^{[25]}$ The results of our study were in accordance with the relevant literature; and suggested that oral health might be impaired with the extension of mechanical ventilatory treatment. 
Table 4. Comparison of bacteria identified in oral culture on day 1 and day 4 according to groups

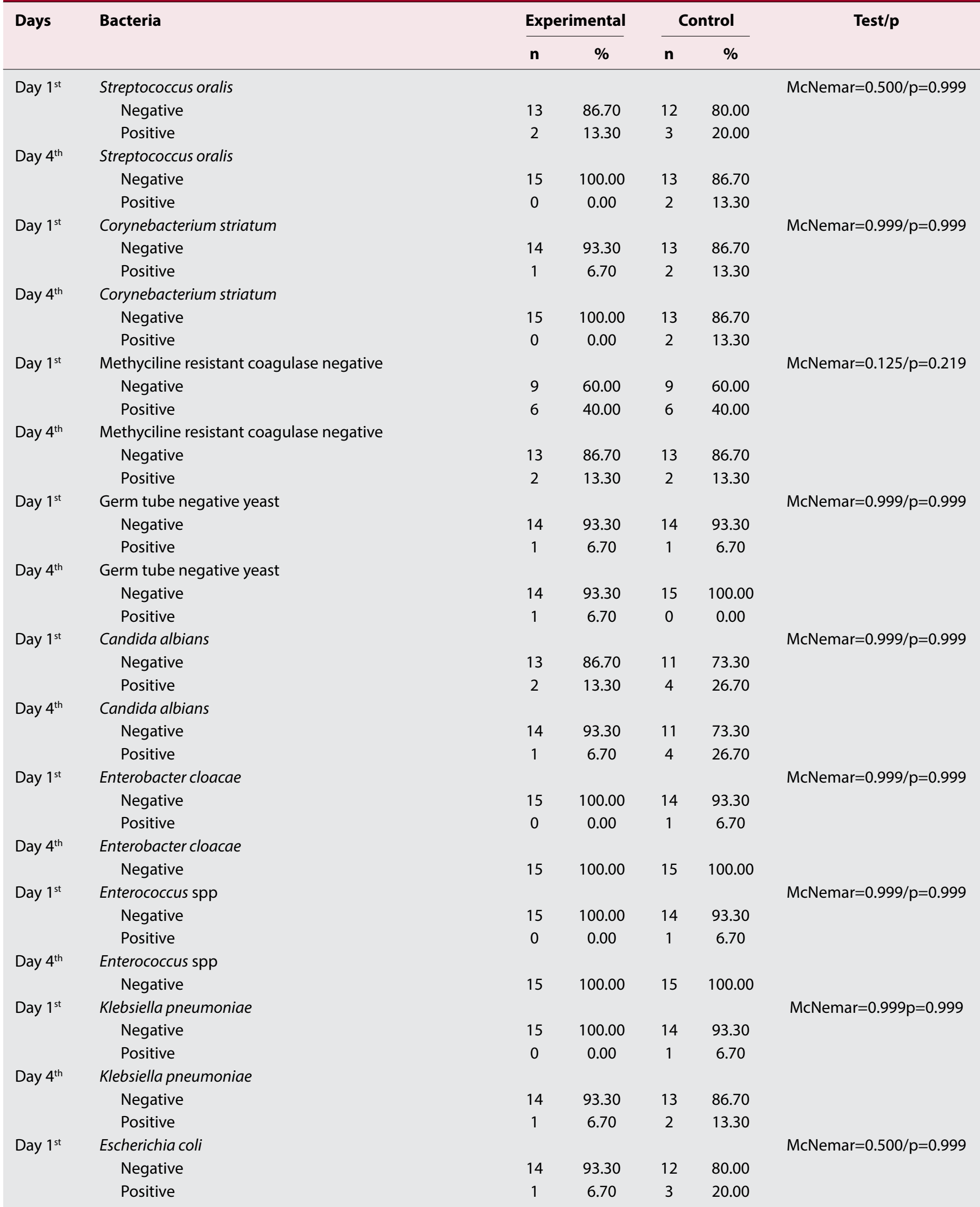


Table 4 (Cont.). Comparison of bacteria identified in oral culture on day 1 and day 4 according to groups

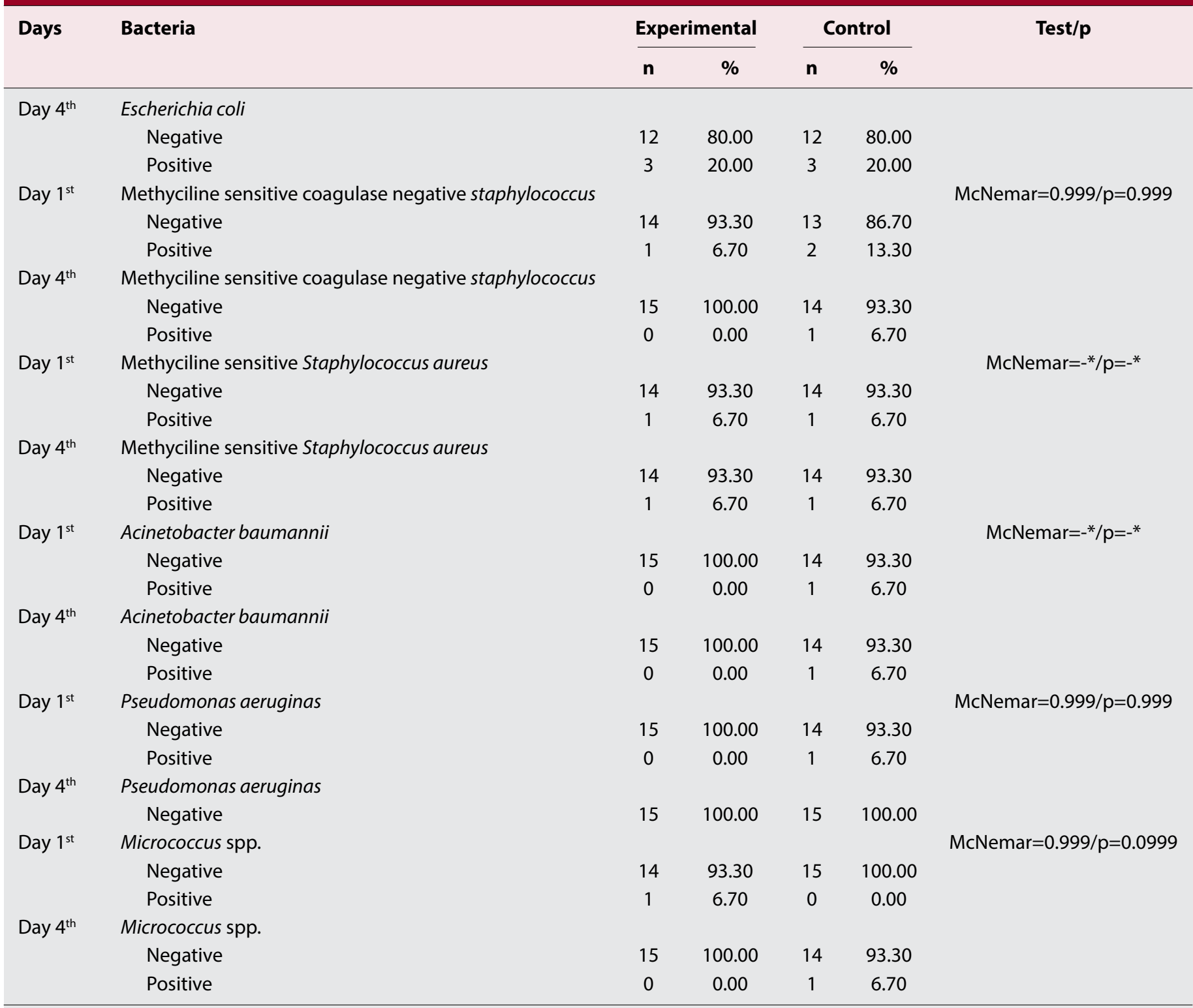

*No statistical analysis.

\section{Conclusions and Suggestions}

It was concluded in this study that both methods used were effective in oral care and they did not have advantage over each other. It was recommended to prefer using soft toothbrushes and to perform oral care regularly based on oral care protocols in order to remove dental plaques and to maintain oral hygiene among the patients on mechanical ventilatory support.

Conflict of interest: There are no relevant conflicts of interest to disclose.

Financial Disclosure: This study was supported by Zonguldak Bülent Ecevit University Scientific Research Projects Coordinator (Project No: 2016-19093093-01).

\section{References}

1. Kayış M. Effects of different concentrations of clorhexidine gluconate used for oral care on oral flora. Acıbadem University Health Sciences Institute. İstanbul; 2014.

2. Abidia R. Oral care in the intensive care unit: A review. J Contemp Dent Pract 2007;8(1):1-8.

3. Dikmen Y. Oral care management in intensive care patient: Literature review within the framework evidence based practices. J DU Health Sci Inst 2017; 7(1): 45-52.

4. Özveren $\mathrm{H}, \mathrm{Uçar} \mathrm{H}$. Effects of oral care provided with three different tools in patients receiving mechanical ventilation. JHS 2017;14(4): 4507-4519.

5. Malkin B. The importance of patient's oral healt hand nurses' role in assessing and maintaining it. Nurs Times. 2009; 105-17.

6. Weber CD. Applying adult ventilator-associated pneumonia bun- 
dle evidence to the ventilated neonate. Advances in Neonatal Care 2016;16(3): 178-190.

7. Grap MJ, Munro CL, Unoki T, Hamilton VA, Ward KR. Ventilatorassociated pneumonia: The potential critical role of emergency medicine in prevention. J Emerg Med 2012; 42: 353-362.

8. Berry AM, Davidson PM, Masters J, Rolls K, Ollerton R. Effects of three approaches to standardized oral hygiene to reduce bacterial colonization and ventilator associated pneumonia in mechanically ventilated patients: A randomised control trial. Int J Nurs Stud 2011; 48(6): 681-8.

9. Cutler C, Davis N. Improving oral care in patients receiving mechanical ventilation. AJCC 2005; 14 (5): 389-394.

10. Ali NS. Critical care nurses' knowledge and compliance with ventilator associated pneumonia bundle at cairo university hospitals. JEP 2013; 4(15): 66-78.

11. Atay $S, K a r a b a c a k$ Ü. Oral care in patients on mechanical ventilation in intensive care unit: Literature review. Int J Res Med Sci. 2014; 2(3): 822-9.

12. Berry A, Davidson P, Rolls K, Masters J. Systematic literature review of oral hygiene practices for intensive care patients receiving mechanical ventilation. AJCC 2007; 16 (6): 552-562.

13. Ames NJ. Evidence to support tooth brushing in critically ill patients. AACN 2011; 20(3): 242-251.

14. Eilers J, Berger A, Petersen M. Development testing and application of the oral asssesment guide. ONF 1988; 15: 325-330.

15. Yates J. The rol of a meticulous oral hygiene program in reducing oral assessment scores, mucosal plaque scores, colonization of dental plaque and exposotionto pathogn colonization that may lead to nosocomial respiratory infections in a selected ıcu patient population, George Mason University; 2002.

16. Kohlerschmidt DJ, Musser KA, Dumas NB. Identification of aerobic gram- negative bacteria. Edit: Goldman E, Green HL. Practical Handbook of Microbiology $2^{\text {nd }}$ ed. Taylor\&Francis Group; 2009.
17. Needleman IG, Hirsch NP, Leemans $M$, et al. Randomized controlled trial of tooth brushing to reduce ventilator associated pneumonia pathogens and dental plaque in a critical care unit. J Clin Periodontol 2011; 38(3): 246-52.

18. Marino PJ, Hannigan A, Haywood S, et al. Comparison of foam swaps and toothbrushes as oral hygiene interventions in mechanically ventilated patients: A Randomised split mouth. Study BMJ Open Resp Res 2016;14(3):1-10.

19. Boop M, Darby M, Loftin K, Broscious S. Effect of daily oral care with $0.12 \%$ chlorhexidine gluconate and a standart oral care protocol on the development of nosocomial pneumonia in intubated patients: A pilot study. J Dent Hygiene 2006; 80 (3): 1-13.

20. Mori H, Hirasawa H, Oda S, Shiga H, Matsuda K, Nakamura N. Oral care reduces incidence of ventilator-associated pneumonia in ICU populations. Intensive Care Med. 2006; 32: 230-36.

21. Alhazzani W, Smith O, Muscedere J, Medd J, Cook D. Tooth brushing for critically ill mechanically ventilated patients: a systematic review and meta analysis of randomized trials evaluating ventilator associated pneumonia. Crit Care Med. 2013; 41: 646-55.

22. Munro CL, Grap MJ, Jones DJ, Mc Clish DK, Sessler CN. Chlorhexidine, tooth brushing, and preventing ventilator associated pneumonia in critically ill adults. Am J Crit Care 2009; 18(5):428-437.

23. Roca Biosca A, Anguera Saperas L, García Grau N, Rubio Rico L, Velasco Guillén MC. Prevention of mechanical ventilator-associated pneumonia: A comparison of two different oral hygiene methods. Enferm Intensiva. 2011; 22: 104-111.

24. Yao LY, Chang CK, Maa SH, Wang C, Chen CC. Brushing teeth with purified water to reduce ventilator associated pneumonia. J Nurs Res. 2011; 19: 289-9.

25. Heo SM, Haase EM, Lesse AJ, Gill SR, Scannapieco FA. Genetic relationships between respiratory pathogens isolated from dental plaque and bronchoalveolar lavage fluid from patients in the intensive care unit undergoing mechanical ventilation. Clin Infect Dis 2008; 47(12):1562-1570. 